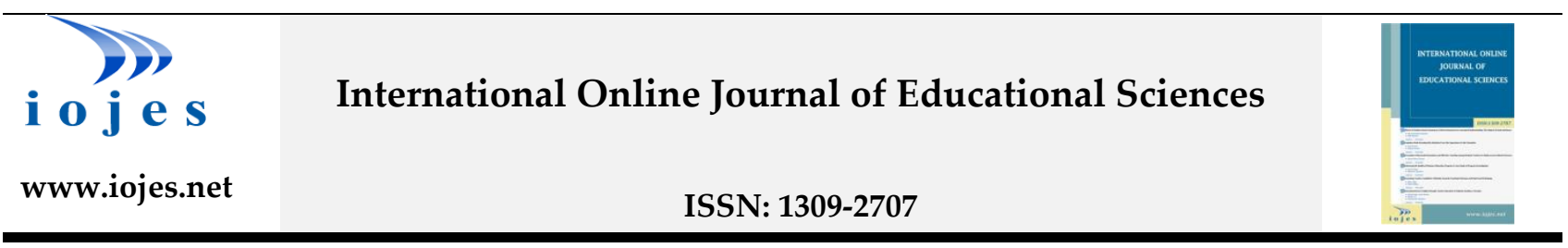

\title{
Mobile Art Applications Acceptance Scale - Validity and Reliability Study
}

\section{Research Article}

\author{
Fatih KARIP1, Yahya HICYILMAZ ${ }^{2}$ \\ ${ }^{1}$ Ağrn İbrahim Çeçen University, Faculty of Education, Department of Social Science Education, Ağrl, Turkey, ORCID: 0000-0002-8957-1568 \\ ${ }^{2}$ Van Yüzüncü Yıl University, Faculty of Education, Department of Social Science Education, Van, Turkey, ORCID: 0000-0003-3453-9998
}

To cite this article: Karip, F., \& Hicyilmaz, Y. (2021). Mobile art applications acceptance scale - validity and reliability study, International Online Journal of Educational Sciences, 13(4), 984-995.

\begin{abstract}
ARTICLE INFO
ABSTRACT

Article History:

The purpose of this study is to develop an acceptance scale whose reliability and validity were tested

Received: 20.07.2020 for the use of m-art applications for Visual Arts preservice teachers. Mobile art applications acceptance scale was tried to determine the theoretical framework based on Davis' (1989) technology

Available online: acceptance model. The study group was formed with 446 Visual Arts preservice teachers studying in 22.01.2021 three different universities with an Art teaching program in the Eastern Anatolia Region. In order to determine the structure of the scale, EFA was performed and CFA was used to verify this structure through SPSS 17.0 software. The fit indices of the structure obtained for the scale $(\chi 2 / \mathrm{sd}=1.93$, RMSEA $=.074, \mathrm{SRMR}=.069, \mathrm{NFI}=.93, \mathrm{NNFI}=.96, \mathrm{IFI}=.97, \mathrm{CFI}=0.97$ and GFI $=0.85)$ show acceptable fit according to Brown (2006), Sümer (2000), Meydan and Şeşen (2011) and Seçer (2013). In this respect, it was seen that the factor structure obtained from EFA as a result of CFA has acceptable fit. Cronbach alpha $(\alpha)$ internal consistency coefficient was found .869 for 19 items of the scale.In scale studies, Cronbach Alpha value is reliable with measurements of .70 and above (Büyüköztürk, 2004; Nunnaly \& Bernstein, 1994). It can be said that the measurements obtained in this direction are evidence for the reliability of the scale.
\end{abstract}

(ㄷ) 2021 IOJES. All rights reserved

Keywords:

Mobile Art Applications, Arts preservice teachers, Acceptance Scale, Validity, Reliability

\section{Introduction}

In today's world, one of the most important skills in terms of maximizing the productivity is the ability to use information technologies. Especially, considering the speed of technological developments, using information technologies alone is insufficient. At the same time, it is necessary to stay up-to-date with these developments. Although some tools such as board, chalk, eraser (Uşun, 2006) are defined as educational technology, the most common concepts are computer, computer softwares, smart board, internet, and artificial intelligence. Educational technologies have entered a period, which is called the automation and cybernation period today, that can change the structure of the future school system, and

${ }^{1}$ Corresponding author's address: Ağrı İbrahim Çeçen University

Telephone: +905068782891

e-mail: fkarip@agri.edu.tr

DOI: https://doi.org/10.15345/iojes.2021.04.003 
eliminate the classical teaching approach (Vural, 2014). Naturally, this transition cannot happen suddenly. At this stage, it might therefore be argued that the process of integration of technology into classical learning has begun. In this sense, blended education is used as an important approach that combines online technologies together with face-to-face education, and takes advantage of their superiority during the teaching-learninng processes (Kocaman Karaoğlu, Kiraz, \& Özden, 2014). Recent studies suggests that the information technologies offered for the purpose of supporting the educational activities carried out face to face make a significant contribution (Fakomogbon, Bolaji, 2017).

One of the important information technologies that are increasingly used in the learning environment is mobile phone applications. Mobile learning is a form of learning that occurs as a result of the integration of mobile computing and e-learning areas and enables access to e-learning content, utilizing dynamically produced services and communicating with others, regardless of a particular location (Ağca, Bağcl, 2013). The main difference that distinguishes mobile learning from other learning activities is that the learning processes continue even if the learner is constantly on the move. It is an important privilege that the individual can start the learning process wherever and whenever $\mathrm{s} / \mathrm{he}$ wants and intervene in the process at any time by staying independent from time and space (Çakır, 2011). Students, who benefit from the opportunities of developing technology with mobile applications, can learn at their own pace, unlike the classical education. In this self-learning process, the students can do research, determine their direction and repeat the topics they want or have problems (Delil, 2017). It has been observed that mobile applications offer effective and productive use and arouse students' curiosity, increase academic achievement and make learning simpler and fun with abstract and technical subjects, make students feel safe and make learning more permanent (Demir \& Akpınar, 2016).

\section{Mobile Art (M-Art) Applications}

Mobile learning can be defined as the use of portable technologies in support of education. Mobile phones, smartphones, tablet computers and laptops may be included in this definition. According to this definition, it can be said that mobile learning takes place in the portability spectrum of e-learning (Traxler, 2005). Mobile learning contributes to reducing education costs in terms of providing independence from time and space, creating and delivering instant multimedia content. In addition, it provides important contributions to education in terms of providing lifelong and needy learning and improving the literacy level especially among young adults (Bulun, Gülnar, Güran, 2004; Mehdipour, Zerehkafi, 2013).

As mobile learning allows to establish the connection between learning inside and outside the classroom, it is imperative for educational institutions to provide mobile devices to students or to develop tools and software suitable for their devices (Demir \& Akpınar, 2016). Mobile technologies are developing more and more every single day, especially with the rapid advances in information technologies in recent years, image transfer during speech, faster data transfer, high quality in all areas, more economical communication, and personalized service opportunities (Çakır, 2011). With these software, many teaching services are provided in various areas from language education to health, from literature to art, such as taking notes, solving problems, running projects, presenting exhibitions or participating. The m-arts practices, which are important components of education, inform us about the cultural and artistic activities that take place all over the world. It contains important information for those who want to prepare their works of art more professionally. It provides access to artists from all over the world to obtain current art ideas. Applications that make important contributions in many areas from encyclopedic knowledge to virtual reality, affects the quality of art works by increasing our art accumulation. It contributes, with important tips, to all art works from photography art to all kinds of paint techniques, from traditional arts to three-dimensional works. These practices, which have become widespread all over the world, have turned into important sources of artists. 


\section{Technology Acceptance Model}

There are many models regarding technology acceptance. However, Davis's model is one of the most preferred, expanded and adapted models used by researchers. Within the scope of his doctoral dissertation, presented in 1986, Davis has brought a new model to the acceptance research literature with his work having a sound theoretical background and testability. The technology acceptance model (TAM) was developed in order to reveal the attitudes and usage behaviors of individuals towards technological tools and to disclose the role that these systems will play in human life in the future. TAM basically refers to a structure that includes cognitive and psychological factors that are effective in accepting a technology for its use. In this context, TAM has been developed to determine the technology preferences of people, to reveal how they might react to change and to explain the reasons why people are resistant to the use of information technologies, and to foresee how they will respond to change (Davis, 1987; Uğur, Turan, 2016; Yıldırır and Kaplan, 2019).

The ability of individuals to use a technology depends primarily on the perception of that tool as useful and easy to use. In the model, perceived utility and perceived ease of use for technology are affected by external variables and affect the attitude towards the use. The attitude towards the use means that the individual has a positive or negative attitude towards technology. Attitude, on the other hand, affects the intention to use the vehicle and as a result of the intention, the behavior of using the vehicle takes place (Fig. 1) (Canan Güngören, Bektaş, Öztürk, Horzum, 2014).

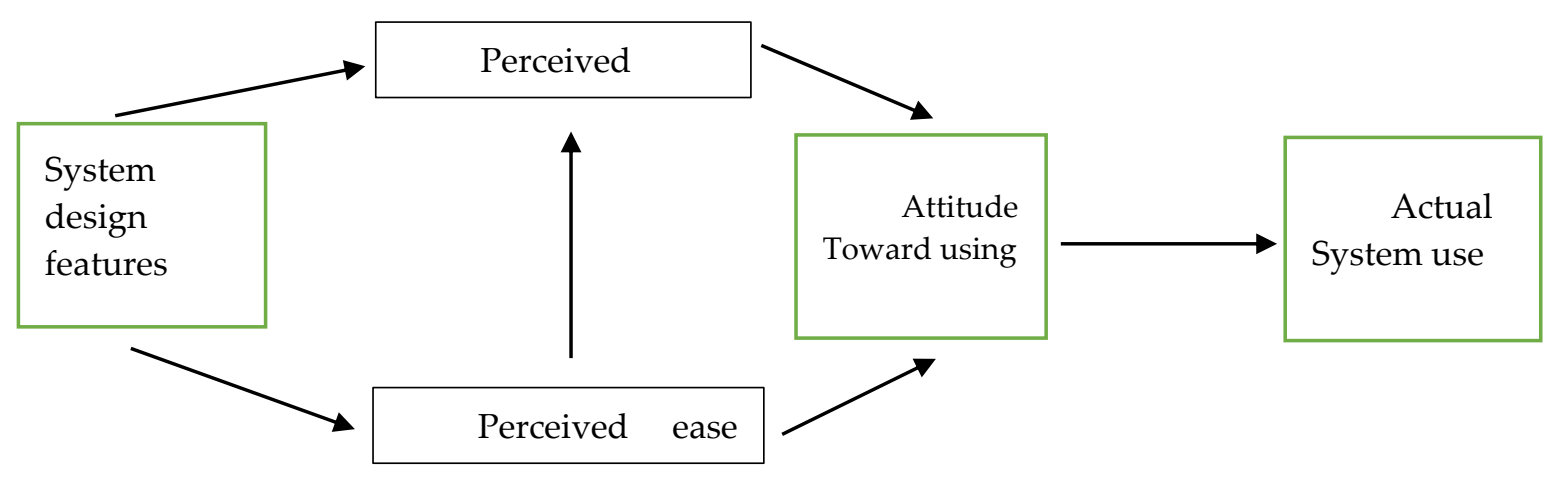

Figure 1. Technology Acceptance Model (Davis, 1993)

TAM, which is the most frequently used model in the literature, has been used in many studies with different samples containing different technologies. When these studies are examined, it is seen that they focused on many different varieties of information technologies such as computers, computer software, tablets (Canan Güngören, Bektaş, Öztürk, Horzum, 2014), e-learning, mobile learning. However, there is no previous research that yielded an acceptance scale specifically prepared for $\mathrm{m}$-art applications, which paved the way for the attempt to conduct the present study by increasing its importance.

\section{Purpose of the Study}

The aim of this work is to develop an acceptance scale for the reliability and validity of Visual Arts teacher candidates for using $\mathrm{m}$-art applications.

\section{Method}

This study is a scale development study that will evaluate the acceptance of the Visual Arts teacher candidates' mobile art applications. 


\section{Study Group}

The study group of the research was formed with 446 Visual Arts teacher candidates studying in three different universities with an Art-Work teaching program in the Eastern Anatolia Region. Data were collected from the study group at two different times for exploratory factor analysis (EFA) and confirmatory factor analysis (CFA). Data were collected from 277 prospective teachers studying at two different universities in the Eastern Anatolia Region for the EFA in the fall semester of the academic year 2019-2020. For the CFA of the study, data were collected from a total of 169 teacher candidates studying at a university in the Eastern Anatolia Region during the spring term. Some researchers state that the sample size should be at least 5 times the number of items on the scale in scale development studies (Bryman \& Cramer, 1999; Gorsuch, 1983; Kline, 2010). Accordingly, it can be said that the working group determined for EFA and CFA is sufficient. Demographic information of the study group is given in Table 1 in detail.

Table 1. Demographic Information about the Study Group

\begin{tabular}{|c|c|c|c|c|}
\hline & Variables & & $\mathbf{n}$ & $\%$ \\
\hline \multirow{7}{*}{ EFA Study Group } & \multirow{2}{*}{ Gender } & Male & 150 & 54,2 \\
\hline & & Female & 127 & 45,8 \\
\hline & \multirow{4}{*}{ Grade Level } & 1. Grade & 70 & 25,3 \\
\hline & & 2. Grade & 77 & 27,8 \\
\hline & & 3. Grade & 65 & 23,5 \\
\hline & & 4. Grade & 65 & 23,5 \\
\hline & Total & & 277 & 100 \\
\hline \multirow{7}{*}{ CFA Study Group } & Gender & Male & 96 & 56,8 \\
\hline & & Female & 73 & 43,2 \\
\hline & Grade Level & 1. Grade & 45 & 26,6 \\
\hline & & 2. Grade & 50 & 29,6 \\
\hline & & 3. Grade & 33 & 19,5 \\
\hline & & 4. Grade & 41 & 24,3 \\
\hline & Total & & 169 & 100 \\
\hline
\end{tabular}

\section{Scale Development Process}

This research aims to develop a scale that will evaluate the acceptance of the Visual Arts teacher candidates' mobile art applications. For this purpose, it is important to determine the theoretical structure of the scale in the first stage (Erkuş, 2016; DeVelis, 2014). Mobile art applications acceptance scale was tried to be based on the theoretical framework set by Davis's (1989) technology acceptance model. Then, by investigating the related literature, the items that measure "perceived benefit", "perceived ease of use", "attitude towards use" and "intention towards use" were determined for the item pool. Based on the works of Biljon and Kotze (2007); Chavoshi and Hamidi, (2019); Davis, (1989); Nikolopoulou, (2018) Park and Yang, (2006); Özer, Özcan and Aktaş, (2010); Uğur, (2016); Wu and Wang, (2005); Yang and Yoo (2004) and Yıldırır and Kaplan (2019) a 30-item item pool has been created. Items in the scale were determined according to Likert-type five-point grading: "I strongly agree" -5, "I agree" -4, "I am indecisive" -3, "I disagree" -2 and "I strongly disagree" -1.

In the second stage, the draft form was presented to the opinions of a group of experts including 1 from Measurement and Evaluation, 1 from Turkish Language and Literature and 2 from Visual Arts Education departments of universities. Expert evaluation can be done by verbal panel method (Erkuş, 2016). In this regard, interviews were conducted with the experts through verbal panel method and continued until a consensus has been arrived on the items. As a result of the meeting, experts decided to remove 8 items in 
the draft form and change the statements in 3 items. Thus, the acceptance scale of mobile art applications has been turned into a draft form consisting of 22 items in align with the opinions of the experts.

In the third stage, a pre-test application was made to 20 prospective teachers on the draft form. As a result of the pre-trial application, no problem was seen in the intelligibility of texts and application environment of the acceptance scale of mobile art applications. At the last stage, the draft form was applied to the scale development sample.

\section{Data Analysis}

The collected data was first coded in the SPSS 17.0 package program. Reverse coding was made for the items with negative expression in the acceptance scale of mobile art applications. Then, missing data and the existence of extreme values were examined. In order to determine the structure of the scale, EFA was performed through SPSS 17.0 package program. To verify this structure determined in the next step, ISER 8.80 package program was used for CFA.

It was checked whether the collected data were normally distributed before starting EFA and CFA. For EFA, skewness value -, 273 and kurtosis value - was 102, and CFA skewness value - 960 and kurtosis value was 540. "The skewness coefficient within the limits of \pm 1.0 can be interpreted as the scores show no deviation from the normal" (Büyüköztürk, Çokluk and Köklü, 2016 p. 48).

\section{Findings}

\section{Findings Regarding Item Analysis}

Before starting the factor analysis, "item-total scale correlations and marks of the scale and internal consistency of the first attempt must be examined" (Erkuş, 2016 p. 101). Accordingly, among the items included in the scale, the items with item total correlations below .30 were first eliminated. In addition, the significance test of the difference between the lower $27 \%$ and upper $27 \%$ groups which was determined according to the total scores of the items in the scale was also examined. Appropriately, the item analysis results of the draft mobile art applications acceptance scale are given in Table 2.

Table 2. Draft Mobile Art Applications Acceptance Scale Item Analysis Results

\begin{tabular}{lll}
\hline Item Number & Item Total Correlations & $\boldsymbol{t}(\text { Lower \% 27-Upper \% 27) })^{* *}$ \\
\hline M1 &, 476 & $-9,034^{* * *}$ \\
M2 &, 424 & $-8,111^{* * *}$ \\
M3 &, 457 & $-9,052^{* * *}$ \\
M4 &, 595 & $-10,720^{* * *}$ \\
M5 &, 521 & $-9,435^{* * *}$ \\
M6 &, 199 & $-4,976^{* * *}$ \\
M7 &, 568 & $-9,530^{* * *}$ \\
M8 &, 441 & $-8,900^{* * *}$ \\
M9 &, 503 & $-8,795^{* * *}$ \\
M10 &, 493 & $-8,533^{* * *}$ \\
M11 &, 356 & $-6,067^{* * *}$ \\
M12 &, 416 & $-6,707^{* * *}$ \\
M13 &, 597 & $-12,139^{* * *}$ \\
M14 &, 495 & $-8,588^{* * *}$ \\
M15 &, 315 & $-6,130^{* * *}$ \\
M16 &, 372 & $-7,723^{* * *}$ \\
M17 &, 523 & $-9,300^{* * *}$ \\
\hline
\end{tabular}




\begin{tabular}{lll}
\hline M18 &, 560 & $-11,005^{* * *}$ \\
M19 &, 593 & $-12,526^{* * *}$ \\
M20 &, 519 & $-10,492^{* * *}$ \\
M21 &, 470 & $-8,838^{* * *}$ \\
M22 &, 542 & $-10,139^{* * *}$ \\
\hline $\mathrm{n}=277^{* * *} \mathrm{p}<0,01$ & &
\end{tabular}

When Table 2 is examined, it was seen that the item-total correlations of 22 items in the scale form ranged from .199 to 597. Since item-total correlations with items below .30 were accepted as problematic items (Büyüköztürk, 2004), item 6 was removed from the draft scale form. In addition, the t-value of all items in the scale was found to be significant with $\mathrm{p}<.001$ level. The significant difference between the lower $27 \%$ and the upper $27 \%$ groups was considered as an indication of the internal consistency of the test (Büyüköztürk, 2004).

\section{Findings for EFA}

EFA was performed with the remaining 21 items from the item analysis in mobile art applications acceptance scale. Before starting EFA, the adequacy of the sample was examined using the Kaiser-MeyerOlkin (KMO) value and the suitability of the data for factor analysis using Bartlett's Sphericity value. It has been determined that KMO value is .875 and Barlett's test value is $(\chi 2=2254,030 ; p=0,000)$. KMO value can be evaluated as very well between .80 and .90 (Field, 2005). These findings show that the data can be subjected to EFA.

The theoretical structure of the research is an important basis in determining the number of factors of the scale (Erkuş, 2016). Theoretically, mobile art applications acceptance scale consists of four subdimensions. Evidence for the four-factor structure of the scale is presented with the data obtained from the slope deposit graph. Figure 1 shows the slope deposit graph for the structure of the scale.

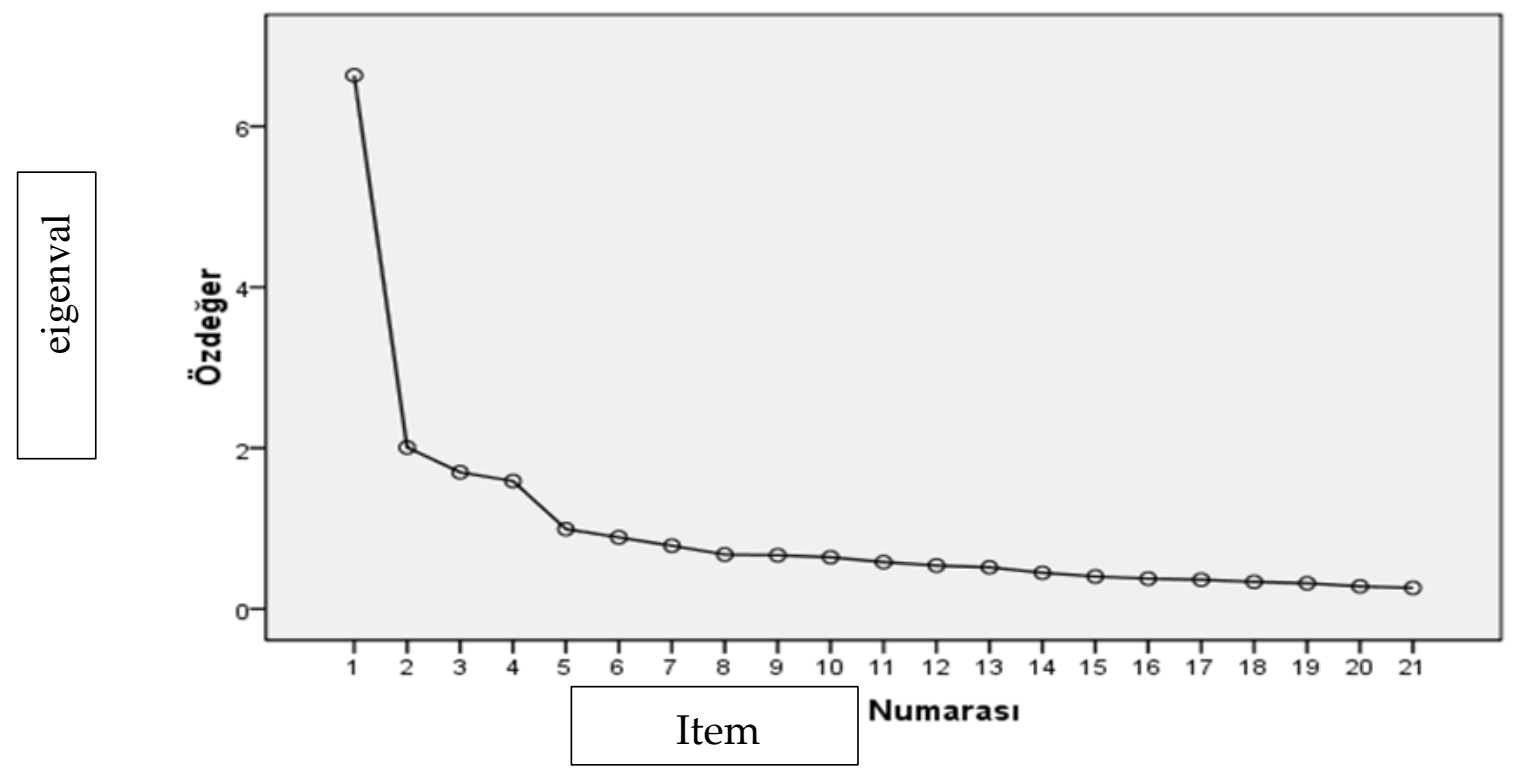

Figure 2. Slope-Accumulation Chart (Scree Plot)

When the theoretical structure of the mobile art applications acceptance scale is examined, subdimensions are considered as unrelated. Such factors are defined as orthogonal (DeVelis, 2014). The use of "Varimax", which is one of the vertical turning techniques, can be expressed as a suitable choice when multifactor structures occur (Büyüköztürük, 2002). Therefore, 21 items of the scale were subjected to basic components analysis with a factor number of four and varimax (25) axis rotation was performed. Factor loads of the items should be checked after the rotation. Load values below .32 (Tabachnick \& Fidell, 2001) 
and overlapping items should be removed from the scale (Büyüköztürk, 2004). As a result of the analyses made in this direction, "M8" and "M13" are accepted as binary substances and are excluded from the analysis. After problematic items are completely removed from the scale, factor common variances of the final mobile art applications acceptance scale and load values after rotation are presented in Table 3.

Table 3. Factor Common Variances of Items of the Final Mobile Art Practices Acceptance Scale and Post-Rotational Load Values

\begin{tabular}{|c|c|c|c|c|c|}
\hline \multirow[t]{2}{*}{ Number } & \multirow[t]{2}{*}{ Factor Common Variance } & \multicolumn{3}{|c|}{ Load Value After Rotation } & \multirow[b]{2}{*}{ KYN } \\
\hline & & AF & AKK & KYT & \\
\hline$\overline{\mathrm{AF} 1}$ & .661 & .792 & & & \\
\hline AF2 & .667 & .813 & & & \\
\hline AF3 & .478 & .621 & & & \\
\hline AF4 & .677 & .766 & & & \\
\hline AF5 & .466 & .637 & & & \\
\hline AF6 & .454 & .536 & & & \\
\hline AKK1 & .529 & & .660 & & \\
\hline AKK2 & .479 & & .605 & & \\
\hline AKK3 & .516 & & .704 & & \\
\hline AKK4 & .476 & & .651 & & \\
\hline AKK5 & .528 & & .622 & & \\
\hline KYT1 & .664 & & & .803 & \\
\hline KYT2 & .718 & & & .822 & \\
\hline KYT3 & .724 & & & .775 & \\
\hline KYN1 & .619 & & & & .734 \\
\hline KYN2 & .660 & & & & .745 \\
\hline KYN3 & .592 & & & & .732 \\
\hline KYN4 & .583 & & & & .744 \\
\hline \multirow[t]{4}{*}{ KYN5 } & .684 & & & & .789 \\
\hline & Eigenvalues & 3.273 & 3.269 & 2.503 & 2.131 \\
\hline & Variance \% & 17.229 & 17.204 & 13.172 & 11.215 \\
\hline & Total Variance \% & & 58.820 & & \\
\hline
\end{tabular}

When Table 3 is analyzed, it is seen that the first dimension, called perceived benefit (AF), consists of 6 items and a factor load value between .536 and .813 . The second dimension of the scale is the perceived ease of use, which consists of 5 items and has a factor load value between .605 and .704 . The third dimension is the attitude towards use (KYT), consisting of 3 items, with a factor load value between .775 and .822 . The fourth dimension is the intention for use, consisting of 5 items, with a factor load value between .7332 and .789 (KYN). In addition, it explains $58.820 \%$ of the total variance of the scale, each of the dimensions determined has an eigenvalue greater than 1, and respectively; it was observed that it had $17.229 \%, 17.204 \%$, $13.172 \%, 11.215 \%$ variance.

\section{Findings for CFA}

CFA is performed to test the accuracy of a specific structure as a model (Çokluk, Şekercioğlu \& Büyüköztürk, 2016). Accordingly, the structure of the mobile arts applications acceptance scale, consisting of 19 items and four factors, was tested with CFA. In the first stage of the analysis, the significance levels of the " $t$ " values and the error variances of the observed variables were examined. It has been determined that " $t$ " values are significant at .01 level and error variances vary between .17 and .72 values. Then, the modification suggestions were examined, and the suggestion for correction between one and two items of the AF factor was made. The path diagram of the first level CFA results of the mobile arts applications acceptance scale is presented in Figure 3. 


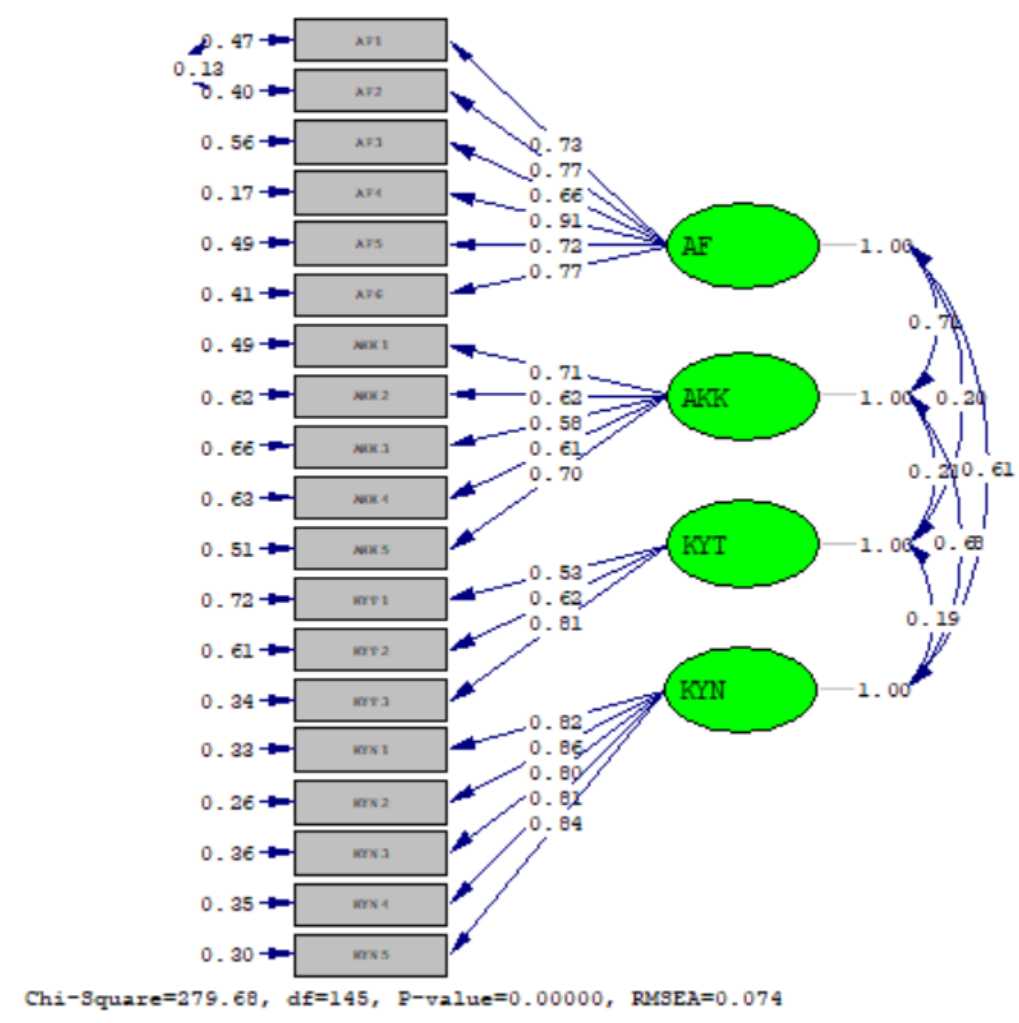

Figure 3. The Path Diagram of the First Level CFA Results of the Mobile Art Applications

$$
\text { Acceptance Scale (Standardized model) }
$$

When Figure 2 is examined, it is seen that the factor loads of the items ranged between .53 and .91. The fact that each item has standardized values of .30 and above indicates that it has an acceptable effect size (Kline, 2010). In the next stage of the analysis, $\mathrm{p}$ value was examined, and it was concluded that $\mathrm{p}$ value was significant ( $\mathrm{p}<.05)$. At the same time, as a result of CFA, $x^{2} / \mathrm{sd}(279.68 / 145)$ ratio was calculated as 1.93 and it was found that it gave a perfect fit value (Çokluk et al., 2016). Information on other fit indexes is presented in Table 4.

Table 4. Values Regarding Fit Indexes for Mobile Art Applications Acceptance Scale

\begin{tabular}{lllll}
\hline Compliance Statistics & Acceptable Limit & Perfect Fit Limit & Source & $\begin{array}{c}\text { First } \\
\text { Level } \\
\text { Adjustment Values } \\
\text { of the Scale }\end{array}$ \\
\hline RMSEA & $\leq .08$ & $\leq .05$ & Sümer (2000) & .074 \\
SRMR & $\leq .08$ & $\leq .05$ & Brown (2006) & .069 \\
NFI & $\geq .90$ & $\geq .95$ & Sümer (2000) & .93 \\
NNFI & $\geq .90$ & $\geq .95$ & Sümer (2000) & .96 \\
IFI & $\geq .90$ & $\geq .95$ & Meydan ve Şeşen, (2011) & .97 \\
CFI & $\geq .90$ & $\geq, 90$ & Sümer (2000) &, 97 \\
GFI & $\geq, 85$ & Seçer, 2013 &, 85 \\
\hline
\end{tabular}

When Table 4 is analyzed, it is seen that RMSEA, SRMR, NFI and GFI fit indexes are acceptable and fit indexes such as NNFI, IFI and CFI are excellent. Accordingly, evidence has been provided to validate the mobile art applications acceptance scale, which consists of 19 items, as a 4 -factor structure model. 


\section{Findings for Reliability}

Cronbach alpha $(\alpha)$ internal consistency coefficient and item total correlations were investigated to obtain evidence for the reliability of the mobile art applications acceptance scale. Cronbach alpha $(\alpha)$ internal consistency coefficient was found .869 for 19 items of the scale. When the item-total correlations of the items with the last form of the scale were analyzed, it was determined that it was between .602 and .330. In addition, the Cronbach alpha $(\alpha)$ internal consistency coefficient of each factor was .827 for calculated AF; It was observed that it was .722 for AKK, .775 for KYT and .850 for KYN. Cronbach Alpha value should be .70 and above in scale development studies (Büyüköztürk, 2004). It can be said that the values obtained in this direction show evidence of the reliability of the scale.

\section{Discussion, Conclusion and Suggestions}

With the latest technological developments in mobile devices such as smartphones and tablet computers, individuals have easy access to information. Also, with mobile technologies, mobile applications are developing rapidly and used in art education. Visual Arts teacher candidates are asked to use their mobile applications effectively in the art education process. Accordingly, it is important for teacher candidates to determine their perceptions about the acceptance of mobile art applications. In this context, it is aimed to develop Mobile Art Applications Acceptance Scale based on technology acceptance model.

Theoretical framework of the mobile art applications acceptance scale was tried to be determined based on Davis' (1989) technology acceptance model. In this direction, a pool of items consisting of 30 items in 5-point Likert type was created by investigating the literature with the deductive approach method. In line with the opinions of the experts, 8 items were removed from the scale. Thus, a draft measurement tool with 22 items was obtained. The draft form of the scale was applied to 277 Visual Arts teacher candidates. As a result of the EFA, a structure consisting of 19 items and consisting of "perceived benefit", "perceived ease of use", "attitude towards use" and "intention towards use" has emerged. CFA was performed to determine the degree of verification of the determined structure. The final form resulting from the EFA was applied to 169 prospective teachers. The fit indexes of the structure obtained for the scale $(\chi 2$ / sd $=1.93$, RMSEA $=.074$, $\mathrm{SRMR}=.069, \mathrm{NFI}=.93, \mathrm{NNFI}=.96, \mathrm{IFI}=.97, \mathrm{CFI}=0.97$ and GFI $=0.85)$ show acceptable compliance with Brown (2006), Sümer (2000), Meydan and Şeşen, (2011) and Seçer (2013). In this respect, it was seen that the factor structure obtained from EFA as a result of CFA has acceptable fit. Cronbach alpha $(\alpha)$ internal consistency coefficient was found .869 for 19 items of the scale. In scale studies, Cronbach Alpha value of .70 and above is regarded as reliable. (Büyüköztürk, 2004; Nunnaly \& Bernstein, 1994).

Visual Arts teacher candidates use various mobile applications in art learning processes, especially in workshop lessons. In this respect, it is very important to determine the correct acceptance of the pre-service teachers' mobile art applications and to carry out research aimed at increasing the acceptance levels of the pre-service teachers. In addition, when the literature is examined, it is seen that there is no previous study on the Visual Arts teacher candidates' acceptance of mobile art applications. In this case, it is thought that the present study may fill this gap in the literature. In the study, pre-service teachers were not included in different sample study groups according to the main art workshop type (painting, graphic, etc.). However, Hiçyllmaz and Inam Karahan (2018) stated in their study that there is a significant difference between the technological knowledge of prospective teachers and the main art workshop type. In this respect, different studies can be carried out by taking samples from prospective teachers studying in different main art workshops for future research. 


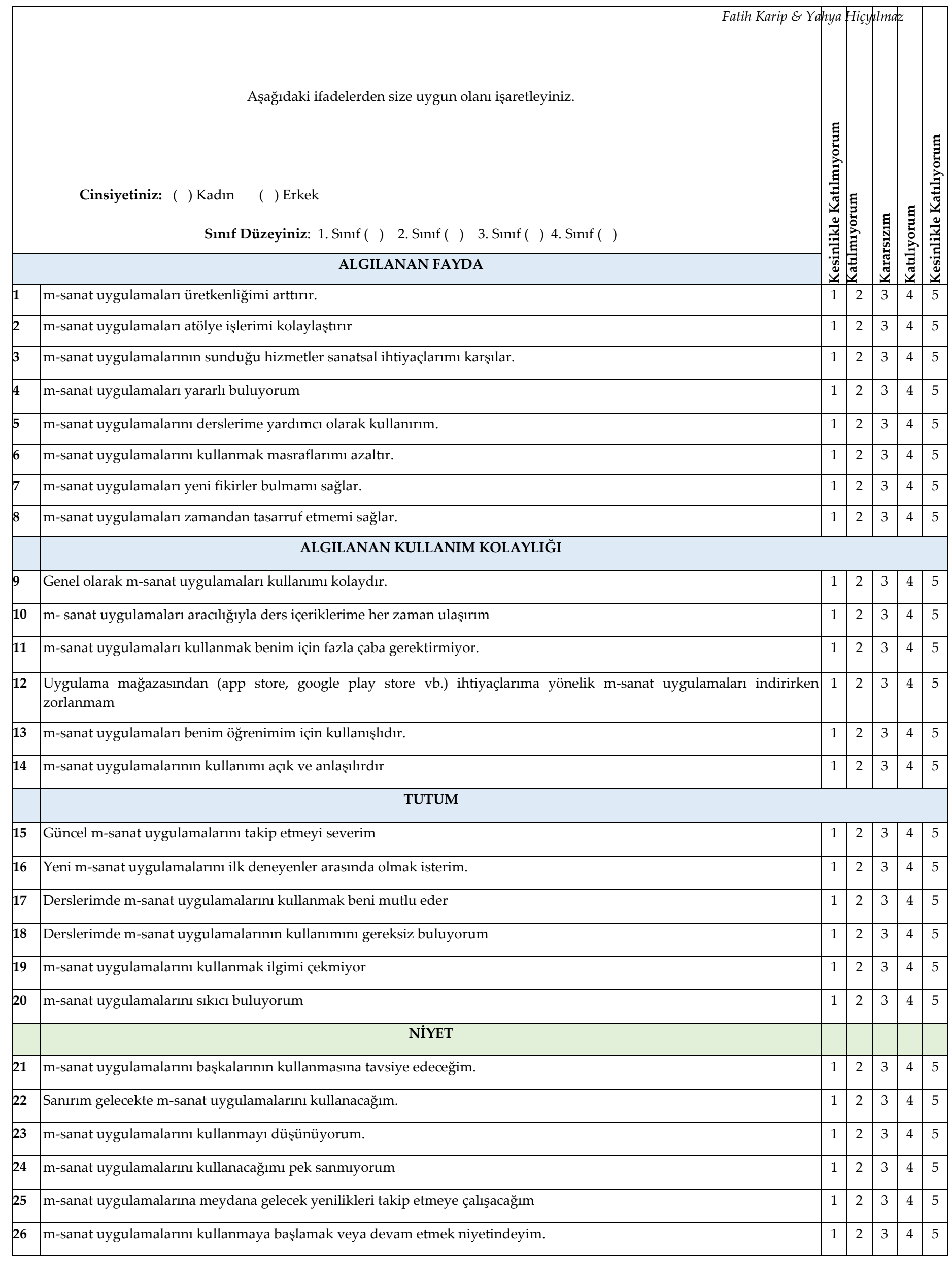




\section{REFERENCES}

Ağca, R.K., Bağcl, H. (2013). Eğitimde Mobil araçların kullanımına ilişkin öğrenci görüşleri, Eğitim ve Öğretim Araştırmaları Dergisi, 2(4), 295-302.

Biljon, J., P. Kotze (2007), Modelling the Factors That Influence Mobile Phone Adoption. ACM, 152-161.

Brown, T. A. (2006). Confirmatory Factor Analysis for Applied Research. New York, NY: Guilford Press.

Bryman, A., \& Cramer, D. (1999). Quantitative Data Analysis with SPSS Release 8 For Windows. London and New York, Taylor \& Francis e-Library, Routledge.

Bulun, M., Gülnar, B., Güran, M.S. (2004). Eğitimde mobil teknolojiler, The Turkish Online Journal of Educational Technology, 3(2), 165-169.

Büyüköztürk, Ş. (2002). Faktör analizi: Temel kavramlar ve ölçek geliştirmede kullanımı. Kuram ve uygulamada eğitim yönetimi, 32(32), 470-483.

Büyüköztürk, Ş. (2004). Sosyal bilimler için veri analizi el kitabı (4. Baskı). Ankara: Pegem Akademi Yayıncllı.

Canan Güngören, Ö., Bektaş, M., Öztürk, E. (2014). Tablet bilgisayar kabul ölçeği geçerlik ve güvenirlik çalışması, Eğitim ve Bilim, 39(176), 69-79.

Chavoshi, A., \& Hamidi, H. (2019). Social, individual, technological and pedagogical factors influencing mobile learning acceptance in higher education: A case from Iran. Telematics and Informatics, 38, 133165.

Çakır, H. (2011). Mobil Öğrenmeye ilişkin bir yazılım geliştirilme ve değerlendirilme, Çukurova Üniversitesi Ĕ̆itim Fakültesi Dergisi, 2(40), 1-9.

Çokluk, Ö., Şekercioğlu, G., ve Büyüköztürk, Ş. (2016). Sosyal bilimler için çok değişkenli istatistik SPSS ve Lisrel uygulamaları (4. Baskı). Ankara: Pegem Akademi.

Davis, F.D. (1987). User Acceptance of information systems: The technology acceptance model (TAM), International Journal of Man-Machine Studies, 38(3), 475-487.

Davis, F. D. (1989). Perceived usefulness, perceived ease of use and user acceptance of information technology. MIS Quarterly, 13(3), 319-339.

Delil, S. (2017). Mobil cihazların bir eğitim materyali olarak kullanımı: Doğru tasarlanmış mobil eğitim uygulamalarının öğrenime katkısı, International Journal of Social Sciences and Education Research, 3(1), 200-207.

Demir, K., Akpınar, E. (2016). Mobil öğrenmeye yönelik tutum ölçeği geliştirme çalışması, Eğitim Teknolojisi Kuram ve Uygulama, 6(1), 59-79.

De Vellis, R.F. (2014). Ölçek Geliştirme: Kuram ve Uygulamalar (T. Totan Çev. Ed.). Ankara: Nobel Yayıncılık.

Erkuş, A. (2016). Psikolojide ölçme ve ölçek geliştirme (3. Baskı). Ankara: Pegem Akademi Yayınları.

Fakomogbon, M.A., Bolaji, H.O. (2017). Effects of Collaborative Learning Styles on Performance of Students in a Ubiquitous Collaborative Mobile Learning Environment, Contemporary Educational Technology, $8(3), 268-279$

Field, A. (2005). Discovering statistics using SPSS (2nd ed.). London: Sage.

Gorsuch, R. L. (1983). Factor analysis (2nd. ed). Hillsdale, NJ: Erlbaum. 
Hiçyılmaz, Y., ve İnam Karahan Ç., (2018). Görsel Sanatlar Öğretmen Adaylarının Teknolojik Pedagojik İçerik Bilgisi Öz Yeterlikleri. Asos Journal, 74, 102-123

Kline, R. B. (2010). Principles and practice of structural equation modeling (3rd ed.). New York: Guilford Press.

Kocaman Karaoğlu, A., Kiraz, E., Özden, M.Y. (2014). Yükseköğretimde Karma bir Dersin Tasarımında İyi Uygulama İlkeleri, Eğitim ve Bilim, 39(173), 249-264.

Mehdipour, Y., Zerehkafi, H. (2013). Mobile learning for education: Benefits and challenges, International Journal of Computational Engineering Research, 3(6), 93-101.

Meydan, C. H., \& Şeşen, H. (2011). Yapısal eşitlik modellemesi AMOS uygulamaları. Detay Yayıncılık.

Nikolopoulou, K. (2018). Mobile learning usage and acceptance: perceptions of secondary school students. Journal of Computers in Education, 5(4), 499-519.

Özer, G., Özcan, M., \& Aktas, S. (2010). Muhasebecilerin bilgi teknolojisi kullanımının teknoloji kabul modeli (TKM) ile incelenmesi. Journal of Yasar University, 19(5), 3278-3293

Park, J.K., S.J. Yang (2006), The Moderating Role of Consumer Trust and Experiences: Value Driven Usage of Mobile Technology. International Journal of Mobile Marketing, 1(2), 24-32.

Seçer, İ. (2013). Spss ve Lısrel ile Pratik Veri Analizi, Analiz ve Raporlaştırma. (1. Baskı). Ankara: Anı Yayıncılık.

Sümer, N. (2000). Yapısal eşitlik modelleri: Temel kavramlar ve örnek uygulamalar. Turkish Psychological Articles, 3(6), 49-74.

Tabachnick, B. G. ve Fidel, L. S. (2001). Using multivariate statistics (4. Edition). Boston: Allyn ve Bacon Com.

Traxler, J. (2005). Defining mobile learning, IADIS International Conference Mobile Learning, 261-266.

Uğur, N. G., \& Turan, A. H. (2016). Mobil uygulama kabul modeli: Bir ölçek geliştirme çalişmasi. Hacettepe Üniversitesi İktisadi ve İdari Bilimler Fakültesi Dergisi, 34(4), 97-125.

Uşun, S. (2006). Öğretim Teknolojileri ve Materyal Tasarımı, Ankara: Nobel Yayıncılık

Vural, L. (2014) Eğitim Teknolojisi Tarihi, Öğretim Teknolojileri ve Materyal Tasarımı (Ed. Gülay Ekici), İstanbul: Paradigma Akademi.

Wu, J.H. ve Wang, S.C. (2005), “What Drives Mobile Commerce? An Empirical Evaluation Of The Revised Technology Acceptance Model”, Information \& Management, 42, 719-729.

Yang, H.D., Y. Yoo (2004), It's all about Attitude: Revisiting the Technology Acceptance Model. Decision Support Systems, 38(1), 19-31.

Yıldırır, S. C. ve Kaplan, B. (2019). Mobil uygulama kullanımının benimsenmesi: teknoloji kabul modeli ile bir çalışma. Kafkas Üniversitesi İktisadi ve İdari Bilimler Fakültesi Dergisi, 10(19), 22-51. 